\title{
THE INFLUENCE OF LOCAL CIRCULATION ON THE CONCENTRATION OF CLOUD CONDENSATION NUCLEI (CCN) IN THE BRAZILIAN NORTHEAST SEMI-ARID REGION (NEB)
}

\author{
Gerson P. Almeida ${ }^{1, *}$, João Bosco V. Leal Junior ${ }^{1}$, Vinicius M. Couto ${ }^{1}$, Stephan Borrmann ${ }^{2}$ \\ ${ }^{1}$ Univ. Estadual do Ceará (UECE) \\ ${ }^{2}$ Max-Plack Institut Für Chemie \\ *gerson.almeida@uece.br
}

\section{RESUMO}

Este trabalho descreve observações de aerossóis atmosféricos e espectros de ativação de CCN no Nordeste do Brasil (NEB). O trabalho foca na identificação das fontes governando a concentração dos aerossóis naturais regionais; quantificando as propriedades de solubilidade dos aerossóis como uma função das fontes.

\section{ABSTRACT}

This work describes observations of atmospheric aerosols and CCN activation spectra in NEB. The work focuses on identify the sources governing regional natural aerosol concentrations; quantify the solubility properties of atmospheric aerosols as a function of their sources.

\section{INTRODUCTION}

$\mathrm{CCN}$ are key elements of the hydrological cycle and climate on regional as well as global scales. Elevated concentrations of $\mathrm{CCN}$ tend to increase the concentration of cloud droplets in clouds and decrease its sizes, modifying trends in rainfall (Khain, 2009 and references therein).

One of the central challenges in climate assessment is to describe the spatial distribution of $\mathrm{CCN}$, the contribution of $\mathrm{CCN}$ from anthropogenic source, and the dependence of $\mathrm{CCN}$ efficiency on the size distribution and chemical composition (e.g. McFiggans et al., 2006; IPCC, 2007).

Two main potential sources of aerosol with different solubility can be identified on $\mathrm{NEB}$, with different impact on $\mathrm{CCN}$ properties. The first region is the one under the influence of the sea spray transport, where particles have large solubility. The second main source is defined by dust aerosol regime, far from the coast, where the soil is a source of insoluble aerosols.

\section{METHODOLOGY}

Observations were performed on two different locations on Ceara State, Brazil: one point close to the sea, representing the coastal regime, and a second point inland representing more remote continental conditions.

At the coast the observation point was at the campus of the Ceara State University, UECE (3.7945 S and $38.5576 \mathrm{~W}$ ), which is inside the city. Inland observations were performed on the Urucum hill (5.0382 S and $39.0093 \mathrm{~W}$ ), about $490 \mathrm{~m}$ above sea level. The observation point was about $10 \mathrm{~km}$ east (upwind) from the town of Quixada.

The observations were performed using an Electric Aerosol Charger (EAC), an Optical Particle Counter (OPC) and a counter for cloud condensation nuclei (CCNC). 


\section{RESULTS AND DISCUSSION}

The mean hourly concentration of aerosol (Figure 1) and $\mathrm{CCN}$ at the coast can be explained by considering the mean flow coupled with the local wind system as follows:

During the night concentrations of aerosols and $\mathrm{CCN}$ are very high. Towards the morning, the land breeze develops coupled to the southeast trade winds, producing an offshore wind, whose air mass has a lower concentration of aerosols, as observed around 6 hours. After sun rises continent warms, and produce a decrease in land breeze, the wind intensity increases while its direction turns counter-clockwise, indicating formation of a convergence zone, with air masses coming from sea. The concentration of aerosol and CCN increase until $\sim 10$ hours. At this time, the thermal contrast of the continent to the sea is significant and sea breeze front begins to develop, which move the convergence zone inland. The sea breeze has a maximum around 14 hours, when the $\mathrm{CCN}$ concentration reaches a minimum at the coast for about $1-3$ hours. Next, the thermal contrast decreases, which weakens the sea breeze. As a result, the southeast trade winds is restored, forming a new convergence zone near the coast, and increasing the concentration of aerosols and CCN continuously after 16 hours, when one observe a daily maximum concentration.

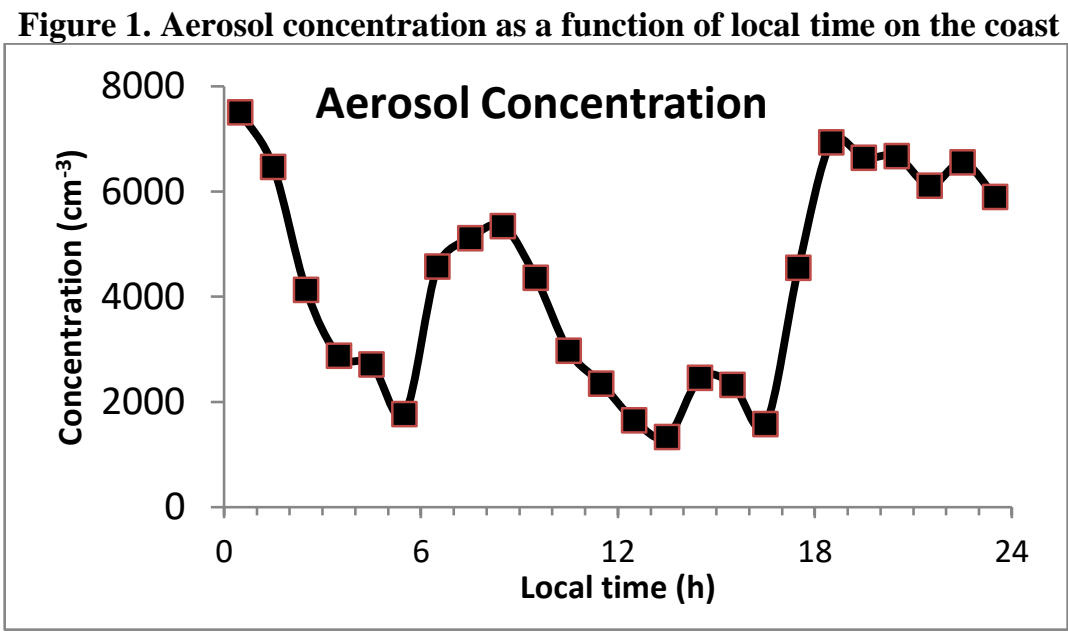

The mean hourly concentration of aerosol and CCN inland can be explained by considering the mean flow wind system (Figure 2). When the wind follows the southeast trade wind, aerosol is formed by resuspension of soil material and exhibit low water solubility. When the wind circulation is significantly modified with unusual northeast flow on the region, marine mass aerosol is advected inland and modifies considerably the solubility of observed aerosols.

\section{CONCLUSÕES}

A remarkable difference between inland and coastal $\mathrm{CCN}$ concentration regimes was found. While in the coastal environment the $\mathrm{CCN}$ concentration follows a daily cycle, the inland observations presented regimes that depend strongly on the back trajectory of the air masses, demonstrating that observed aerosol activation properties here are sensitive with respect to the sources.

The results suggest that on the NEB region the $\mathrm{CCN}$ budget is influenced by longrange transport 
Figure 2. Fraction of aerosol activated as $\mathrm{CCN}$ at $1.5 \%$ supersaturation as a function of the prevail Wind direction

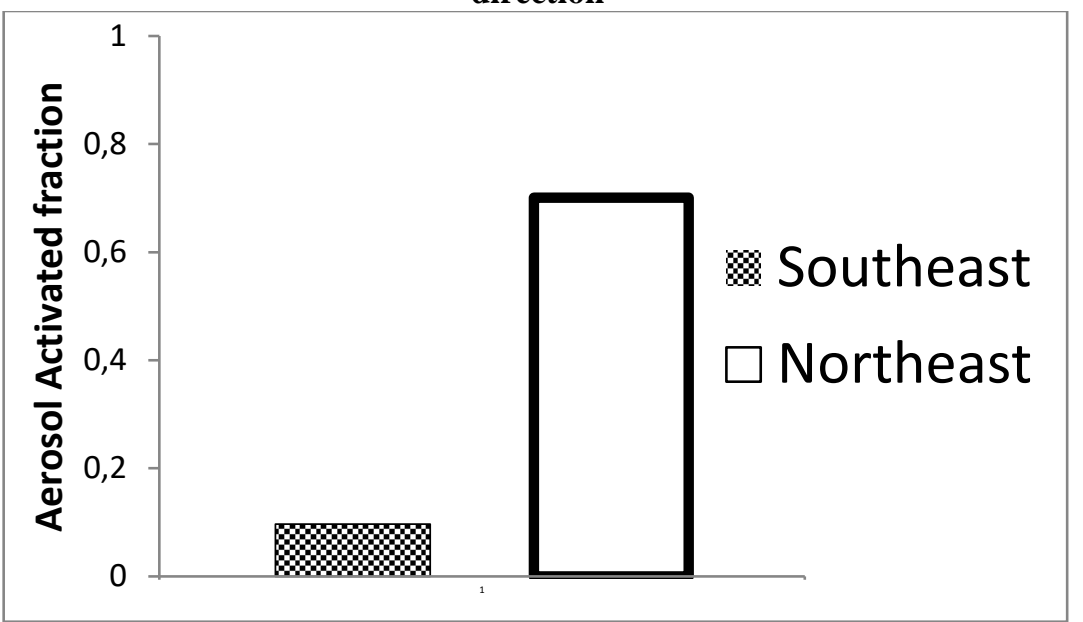

\section{ACKNOWLEDGMENT}

To Funcap and MPIC.

\section{REFERENCES}

Khain AP (2009). Notes on state of the art investigations of aerosol effects on precipitation: A critical review. Environmental Research Letters , 4, 015004.

McFiggans G, et al. (2006) The effect of physical and chemical aerosol properties on warm cloud droplet activation, Atmos. Chem. Phys., 6, 2593-2649.

IPCC: Climate Change (2007) The Physical Scientific Basis, edited by S. Solomon, D. Qin, M. Manning et al., Cambridge Univ. Press, NY, USA. 